\title{
The Effect of Giving Massage, Physiotherapy and Nutritional Needs Based on RDA Numbers Against Increased Endurance of the Legs and Heart Muscles of the Road Racetour De Singkarak Bicycle Racing Athletes
}

\author{
Deri Putra ${ }^{1}$, Nurlan Kusmaedi ${ }^{2}$, Amung Mamun ${ }^{3}$, Syafrudin $^{4}$, Firman Suryadi Rahman ${ }^{5}$ \\ ${ }^{1}$ Doctoral Student of Universitas Pendidikan Indonesia, ${ }^{2}$ Professor at Universitas Pendidikan Indonesia, \\ ${ }^{3}$ Professor at Universitas Pendidikan Indonesia, ${ }^{4}$ Professor an Universitas Negeri Padang, ${ }^{5}$ Faculty of Public \\ Health, Universitas Airlangga
}

\begin{abstract}
This study aims to determine the effect of giving massage, physiotherapy and nutritional needs based on nutritional adequacy rates to increase endurance of leg and heart muscles in the Road Racetour De Singkarak Bicycle Racing Athlete. The sample in this study uses a total sample technique that is all athletes Pelatnas Road Racetour De Singkarak athletes, amounting to 10 people. The findings of this study include, 1) There is an effect of giving massage to increase leg and heart muscle power, with the average rating of the experimental group using the Strocking Effleurage method, traction (traction) and Effleurage more dominant than the average value of the control group. 2) There is an influence of giving physiotherapy to increase leg and heart muscle power, and the administration of control group physiotherapy with Exercise therapy technique is more dominant than the administration of Thermotherapy (Heat therapy/Heat Therapy). 3) There is an influence of nutritional needs based on the nutritional adequacy rate on the increase in leg and heart muscle power of the Road Racetour De Singkarak Road Race, with the average experimental group being more dominant than the control group
\end{abstract}

Keywords: Massage, Physiotherapy, Nutritional, Bicycle Racing Athletes.

\section{Introduction}

Cycling can make the body become healthier and fitter. As stated by Giam \& $\mathrm{Teh}^{1}$ that bicycle sport is one of the branches of aerobic exercise which during its implementation requires oxygen consumption. Therefore, cycling is very beneficial for maintaining and improving the fitness of the heart, lungs, blood circulation, muscles, bones and joints. But in practice, cycling also has risks, both by external factors such as accidents during a race and internal factors in the form of fatigue overuse or posture errors that do not match the shape of the bicycle.

\section{Corresponding Author:}

\section{Deri Putra}

Doctoral Student of Universitas Pendidikan Indonesia, Jl. Dr. Setiabudi 229 Bandung, Indonesia
The sport of bicycle has different characteristics from other sports. In the sport of bicycle, athletes are required to be able to pedal a bicycle as fast as possible with a predetermined distance and mastery of good techniques to get through obstacles in order to create maximum acceleration. Therefore Harsono ${ }^{2}$ emphasized in the physical component table some of the body parts needed in the sport of bicycles, namely: (a) back muscle strength, (b) muscle strength and strength of arm muscles, (c) muscle strength, muscle strength, agility, flexibility, heart muscle strength and leg power.

Physical exercise such as cycling will cause strength and strength of respiratory muscles to increase, so that the ability of the lungs to expand will increase. In addition, physical exercise will result in an increase in the ability of the respiratory muscles to overcome the resistance of respiratory air flow. Indicators of muscle endurance can be measured by facilities, tools, and implementation 
processes. For this reason, the researcher considers that paying attention to athletes physically before and after a bicycle race, such as massage, doing physiotherapy and the nutritional needs of athletes are important things to do. ${ }^{3}$

The problem that always occurs in the world of sports is injuries that often occur due to incorrect techniques and fatigue. Back pain problems are often experienced by bicycle racers. Viewed from several aspects, giving massage, nutrition, or physiotherapy is the first aid for athletes to maintain the physical fitness of athletes to stay fit and the adequacy of good nutrition is believed to improve the athlete's condition during the race.

Based on the background presented above, the researchers are interested in examining the extent of the effect of massage, how much physiotherapy results are, and the extent of the effect of nutritional requirements based on the Nutrition Adequacy Rate (RDA) on increasing endurance of leg and heart muscles in Road Bike Racing Athletes Racetour De Singkarak which will be held in April 2020.

\section{Methods}

Research Design: This study is an experimental study using a Quasy-experiment design defined as an experiment that has treatments, impact measurements, experimental units but does not use random assignments to create comparisons in order to conclude changes caused by treatment with the Pre-test and Post-test nonequivalent control group designs, where the treatment given can make a change or not make a change

The treatment given in this study is the provision of massage, physiotherapy, and nutritional needs based on nutritional adequacy rates to increase endurance of leg and heart muscles during control class meetings and experimental athletes of the Pelatnas bicycle racers, Road Racetour De Singkarak Road Bike Athletes.

Location and Time of the Research: This research was conducted at the training center of the PGN bicycle team which will become the Road Racetour De Singkarak Bicycle Race Athlete during preparation for the race. The training place for the PGN bicycle team is located at Jl. Kaliurang, Yogyakarta City, Yogyakarta DIY Province.

Population and Sample: The population and samples in this study were all Road Racetour De
Singkarak Bicycle Racing Athletes from Pelatnas PGN, amounting to 10 people. The following is a sample table of this study:

The sample in this study consisted of 10 respondents. Researchers divided the two groups of athletes who were given the same treatment of massage, physiotherapy, and nutritional requirements based on the RDA and the increased muscle and heart strength in the experimental and control samples.

\section{Data Collection Techniques and Instruments}

\section{- Data Collection Techniques}

a. The researcher asked for permission to collect research data from the sample who was a Road Racetour De Singkarak bicycle racer with a research permit.

b. Researchers determined a number of study samples from the population, and obtained a total of 10 study samples.

c. The study sample was given a briefing related to the technical instructions for filling in informed consent (the willingness to be a research sample) and the time of the study.

d. The researcher gave research instruments in the form of SOP massage sheets, Physiotherapy and Nutrition Needs based on RDA Numbers with Endurance of Leg and Heart Muscles in Pelatnas Athletes with numerical scale standards to the samples.

e. Researchers took pretest data to control and experimental samples of 10 people. Data taken in the form of endurance value of leg and heart muscles in athletes before receiving national treatment of massage, physiotherapy and nutritional needs based on the RDA figures after being given treatment

f. Experimental samples and research controls were treated in the form of massage, physiotherapy and nutritional needs based on the RDA numbers according to Standard Operational Procedure (SOP).

g. Researchers took posttest data to a sample of 10 people. Data taken in the form of the value of the endurance conditions of the limbs and heart muscles after being given a massage treatment with heat therapy.

h. Researchers collected all raw data from the measurement results, then it was processed using SPSS. 


\section{- Research Instruments}

The instruments used in this study are tools used to obtain the results of the degree of pain in the trapezius muscle, namely: Numeric Rating Scale (NRS) or modified Numerical Scale. Numeric Rating Scale (NRS) which has a score of 0 to 10 . To provide an overview of the instruments used in research, the authors present below:

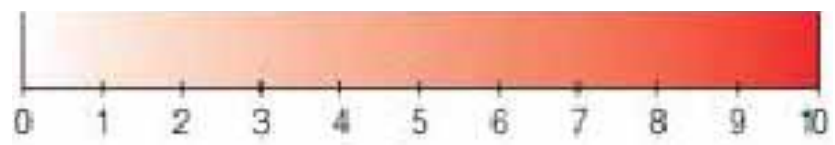

Figure 1. Numeric Rating Scale (NRS) (Berman, 2016: 1097)

Several scales on the modified Numeric Rating Scale (NRS) can be classified as follows:

$\begin{array}{llll}\text { 1. } & \text { Scale } 0 & \text { : } & \text { Very poor } \\ \text { 2. } & \text { Scale 1-3 } & : & \text { Less } \\ \text { 3. Scale 4-6 } & : & \text { Medium } \\ \text { 4. Scale 7-9 } & : & \text { Good } \\ \text { 5. Scale 10 } & : & \text { Very Go }\end{array}$

\section{Results and Discussion}

\section{Research Result}

\section{- Data Description}

- Pretest and Posttest Massage Data on Increased Endurance of Leg and Heart Muscles in Road Racetour De Singkarak Bicycle Racing Athletes

Pretest massage data on increased endurance of leg and heart muscles in the control group were obtained from the results of measurement tests on the study sample, where initial data collection was carried out before the study sample received massage treatment. The final data (posttest) of the massage for the increase in endurance of the leg and heart muscles was obtained from the measurement test results in the study sample, in which the data collection was carried out after the study sample received treatment in the form of sports massage. The following is a description of the pretest and posttest massage data for increased endurance of the leg and heart muscles in the control group.

It can be seen that that there was an increase in massage using the method of pressing at the acupressure point and friction (grinding) to increase endurance of the leg and heart muscles in the control group. Pretest Mean 3.4 and posttest mean 6.4 .

After the researcher made observations in the control group, the next researcher made observations in the experimental group with massage using the Strocking Effleurage, traction and Effleurage methods. The researcher took the pretest data before the treatment was given and then took the posttest data after the sample was treated. The following is a description of the pretest and posttest massage data for increased endurance of the leg and heart muscles in the experimental group:

It can be see that there was an increase in massage using the Strocking Effleurage, traction and Effleurage methods to increase endurance of the leg and heart muscles in the experimental group at the Road Racetour De Singkarak Bicycle Racing Athletes. Pretest Mean 2.6 and posttest mean 7.4 .

- Pretest and Posttest Physiotherapy Data on Increased Endurance of the Leg and Heart Muscles

Data on physiotherapy pretest on increasing endurance of leg and heart muscles in the control group were obtained from the results of measurement tests on the study sample, where initial data collection was carried out before the study sample received physiotherapy treatment. The final data (posttest) of physiotherapy on increasing endurance of leg and heart muscles was obtained from the results of measurement tests on the study sample, in which the data collection was carried out after the study sample received treatment in the form of physiotherapy. The following is a description of the pretest and posttest physiotherapy data for increasing endurance of the leg and heart muscles in the control group.

There was an increase in physiotherapy with exercise therapy therapy (exercise therapy) to increase endurance of leg and heart muscles in the control group. Pretest Mean 2.4 and posttest mean 7.

After the researchers made observations in the control group, then the researchers conducted observations in the experimental group with physiotherapy using the Thermotherapy (Heat therapy / Heat Therapy) technique, the researchers collected the data after the sample performed Thermotherapy (Heat therapy) on the Road Racetour De Singkarak Bicycle Racing Athletes. The following is a description of the pretest and posttest physiotherapy data on the increase in endurance of the 
leg and heart muscles in the experimental group:there was an increase in physiotherapy using Thermotherapy (Heat therapy) techniques to increase endurance of the leg and heart muscles in the experimental group of the PGN Road Racetour Bicycle Athletes.Pretest Mean 2.6 and posttest mean 6.4 .

- Pretest and Posttest Data Nutrition Needs Based on RDAon Increased Endurance of Leg and Heart Muscles

Pretest nutritional data based on RDA for increased endurance of leg and heart muscles in the control group was obtained from the measurement test results in the study sample, where initial data collection was carried out before the study sample received nutritional support under normal circumstances. The final data (posttest) of physiotherapy for increasing endurance of leg and heart muscles was obtained from the results of measurement tests on the study sample, in which the data collection was carried out after the study sample was given nutrition based on the RDA. The following is a description of nutritional pretest and posttest data based on RDA to increase endurance of leg and heart muscles in the control group.

There was an increase in the nutritional requirements based on the RDA with a balanced menu by providing more carbohydrates, protein for increased endurance of the leg and heart muscles in the control group.Pretest Mean 4 and posttest mean 8

After the researchers made observations in the control group, the next researchers conducted observations in the experimental group using other different balanced menus, the researchers took the data after the samples received the nutritional requirements based on the RDA at the Road Racetour De Singkarak Bicycle Athletes. The following is a description of the pretest and posttest data of RDA nutrition for increasing endurance of leg and heart muscles in the experimental group:

There was an increase in nutrition based on the RDA to increase endurance of the leg and heart muscles in the experimental group at the Road Racetour De Singkarak Bicycle Racing Athlete. Pretest Mean 4.6 and posttest mean 8.2.

\section{a Testing the Analysis Prerequisites}

\section{- Normality test}

Based on the results of the analysis, it can be concluded that the pretest and posttest data given to increase athlete's leg and heart muscle power have sig values. $>0.05$ and is at the normal distribution level. Thus, one of the statistical testing requirements has been fulfilled.

\section{- Homogeneity Test}

The next step after the normality test is done, the researcher conducts a homogeneity test, whose purpose is to find out whether the data is homogeneous in a study.

In this step, the probability value (sig.) Obtained from the Lavene statistic for the initial test (pretest) of the control group massage results is 1,000 with a homogeneous description of the experimental group massage results that is 0.617 with homogeneous information, the control group physiotherapy results are 0.169 with homogeneous information, the physiotherapy results of the experimental group were 1,000 with homogeneous information, the results of the AKG nutrition giving control group were 1,000 with homogeneous information, the results of the AKG nutrition giving the experimental group were 0.296 with homogeneous information.

Based on the analysis of homogeneity test using the lavene test (lavene statistics) shows that all pretest and posttest data in each group has a sig value. $>0.05$, means that the pretest and posttest data of the control and experimental groups are homogeneous. Thus both groups are homogeneous and normal so that they meet the requirements for $\mathrm{t}$-tests.

\section{b Hypothesis Testing}

- Effect of Giving Massage Against Increased Leg Muscle Power and Heart

Based on the results of data processing that has been done, the results show that the administration of massage affects the increase in leg muscle power and heart, with the decision criteria for hypothesis testing by comparing the probability value (sig.) With $\alpha=5 \%$. The decision criteria are as follows: (1) if sig. $>0.05$ then $\mathrm{H} 0$ is accepted and $\mathrm{H} 1$ is rejected; (2) if sig. $<0.05$ then $\mathrm{H} 0$ is rejected and $\mathrm{H} 1$ is accepted. Hypothesis test results are presented in the following table: 
Table 1. Paired T Test for Giving Massage

\begin{tabular}{|l|c|c|c|}
\hline \multicolumn{4}{|c|}{ Levene's Test for Equality of Variances } \\
\hline & Sig & t count & Notes \\
\hline Massage Control Results & 0,014 & 3,128 & Significant \\
\hline Experimental Massage Results & 0,000 & 5,657 & Significant \\
\hline
\end{tabular}

It is known from table 1, the t-value for giving massage to the control group was 3.128 with a probability (sig.) Of 0.014 . Because the probability value (sig.) Is $0.014<0.05$, while the $t$-value in the experimental group massage is 5.657 and the probability (sig.) Is 0.000 , because the probability value (sig.) Is $0.000<0.05$, thus $\mathrm{H} 0$ is rejected and $\mathrm{H} 1$ is accepted in the control group. and experimentation. Based on the table above, there is an effect of giving massage to increase the leg and heart muscle power of PGN athletes. Then it can be concluded that there is an effect of giving massage to increase leg and heart muscle power of the Road Racetour De Singkarak Athletes.
- Effect of Physiotherapy Results on Increased Leg and Heart Muscle Power

Based on the results of data processing that has been done, the results show that the administration of physiotherapy has an effect on increasing the power of leg and heart muscle, with the decision criteria for testing the hypothesis by comparing the probability value (sig.) With $\alpha=5 \%$. The decision criteria are as follows: (1) if sig. $>0.05$ then $\mathrm{H} 0$ is accepted and $\mathrm{H} 1$ is rejected; (2) if sig. $<0.05$ then $\mathrm{H} 0$ is rejected and $\mathrm{H} 1$ is accepted. Hypothesis test results are presented in the following table:

Table 2. Paired T Test Physiotherapy

\begin{tabular}{|l|c|c|c|}
\hline \multicolumn{4}{|c|}{ Levene's Test for Equality of Variances } \\
\hline & Sig & $\mathbf{t}$ count & Notes \\
\hline Physiotherapy Control Results & 0,000 & 4,468 & Significant \\
\hline Physiotherapy Results of Experiments & 0,001 & 5,270 & Significant \\
\hline
\end{tabular}

The t-test value for giving physiotherapy in the control group is known to be 4,468 with a probability (sig.) Of 0,000 . Because the probability value (sig.) Is $0.000<0.05$, while the value of t-count in the experimental group physiotherapy is 5.270 and the probability (sig.) Is 0.001 , because the probability value (sig.) Is $0.001<0.05$, thus $\mathrm{H} 0$ is rejected and $\mathrm{H} 1$ is accepted in the control group. and experimentation. Based on the table above, there is an effect of the provision of physiotherapy to the increase in leg and heart muscle power of PGN athletes in the National Racing Road Racetour De Singkarak Bicycle Race. Then it can be concluded that there is an effect of the provision of physiotherapy to the increased muscle power of the legs and heart of the Road Racetour De Singkarak Athletes.

- Effect of Nutrition Needs Based on Nutrition Adequacy Rates on Increased Leg and Heart Muscle Power

Based on the results of data processing that has been done, the results show that the provision of nutritional needs based on the RDA affects the increase in leg and heart muscle power, with the decision criteria for hypothesis testing by comparing the probability value (sig.) With $\alpha=5 \%$. Hypothesis test results are presented in the following table:

Table 3. Paired T Test Nutrition Needs Based on AKG

\begin{tabular}{|l|c|c|c|}
\hline \multicolumn{4}{|c|}{ Levene's Test for Equality of Variances } \\
\hline & Sig & t count & Notes \\
\hline RDA Control nutrition results & 0,000 & 8,944 & Significant \\
\hline RDA Nutrition Results Experiments & 0,002 & 4,648 & Significant \\
\hline
\end{tabular}


The t-count value for the provision of nutritional requirements based on the RDA in the control group was 8,944 with a probability (sig.) Of 0,000 . Because the probability value (sig.) Is $0.000<0.05$, while the value of t-count in the provision of nutritional needs based on the RGG of the experimental group is 4.648 and the probability (sig.) 0.002 , because the probability value (sig.) $0.002<0.05$, thus $\mathrm{H} 0$ is rejected and $\mathrm{H} 1$ accepted in the control and experiment groups. Based on the table above, there is an effect of providing nutritional needs based on the RDA to increase the leg and heart muscle strength of PGN athletes. So, it can be concluded that there is an effect of nutritional needs based on RDA to increase the leg and heart muscle power of the Road Racetour De Singkarak Athletes.

\section{Discussion}

The Effect of Giving Massage on Increased Leg and Heart Muscle Power: The t-value for giving massage in the control group was 3.128 with a probability (sig.) Of 0.014 , because the probability value (sig.) Of $0.014<0.05$. While the t-count in the experimental group massage was 5.657 and the probability (sig.) Was 0.000 , because the probability value (sig.) Was $0.000<0.05$. Thus there is an influence of giving massage to increase the leg and heart muscle power of PGN athletes. Giving massage to the control group in the form of pressing on the acupressure and friction points (grind) and giving massage with the Strocking Effleurage, traction (Effraction) and Effleurage method in the experimental group showed that the use of massage techniques in the experimental group was better than the control group. This can be seen from the average results of 7.40 in the experimental group whose values were higher than the control group which averaged only 6.40 . The more optimal cause of massage in the experimental group was due to the rhythmic Effleurage technique that was performed on the entire surface of the injured body, could reduce pain (bruising), accelerate blood circulation so as to speed up the transport of metabolic remnants, and provide a feeling of calm.

Giving massage manipulation to the control and experimental class both had an effect on increasing athlete's leg and heart muscle power. The reaction before being treated at the tugkai muscle power value and moving heart increased after being treated both the control group and the experimental group. This is because giving massage aims to improve blood circulation. Massage will help the process of solving and removing lactic acid so that the recovery process will be faster. In addition, sports massage is also beneficial to increase muscle suppleness, reduce nerve tension, and reduce pain, so that it can be used to help the recovery process of lower extremity muscle tension.

Giving massage to all members of the body and certain body parts will improve the body's work system. One example is giving massage to the lower extremities at the Road Racetour De Singkarak Bicycle Racing Athlete after doing physical activity or training. The provision of sports massage on the lower extremities at the Road Racetour De Singkarak Road Racing Athletes after exercise will have an effect of accelerating the process of absorbing the remains of combustion that is in the muscle tissue that can cause fatigue so that it is good to help speed up the recovery process. According to Johnson ${ }^{4}$ giving massage will facilitate blood flow, relax muscles, and stimulate the body's work system, so that muscle tension will decrease and muscles will return to normal.

Massage after exercise or physical activity is given after cooling and stretching. This aims to reduce muscle tension and increase the disposal of metabolic waste that occurs after exercise. In addition, efforts are also made to reduce post-exercise pain that occurs immediately or some time after physical work, maintain joint reach and increase blood and lymph circulation in muscles that experience tension. ${ }^{5}$ The benefits of sports massage after exercise can help speed up muscle recovery to be able to return to a state of relaxation and rest. Massage in this situation an increase in venous blood return (venous return) so that it can improve the process of cleaning the rest of metabolism.

It can be concluded that there is an effect of giving massage to increase leg and heart muscle power, with the average rating of the experimental group using the Strocking Effleurage, traction and Effleurage methods more dominant than the average value of the control group.

Effects of Physiotherapy on Increased Leg and Heart Muscle Power: The t-count value for the administration of physiotherapy in the control group was 4.468 with a probability (sig.) Of 0.000 , because the probability value (sig.) Of $0.000<0.05$. While the t-count value in the experimental group physiotherapy was 5.270 and the probability (sig.) Of 0.001 , because the probability value (sig.) Of $0.001<0.05$. Thus there 
is an influence from the provision of physiotherapy to increase the leg and heart muscle power of PGN athletes.

The provision of physiotherapy in the control and experimental groups using two different techniques can affect the increase in leg and heart muscle strength of PGN athletes. The control group that was given physiotherapy techniques, Exercise therapy and the experimental group that was given Thermotherapy (Heat therapy), found that physiotherapy with Exercise therapy techniques was more dominant than the administration of Thermotherapy (Heat therapy / Therapy) Hot). It can be seen that the comfort felt by the control group athletes is 7.00 higher than the experimental group with an average of 6.40 .

According to Johnson physiological administration is proven to reduce heart rate, increase blood pressure, increase blood and lymph circulation, reduce muscle tension, and increase joint space and reduce pain. Providing exercise therapy techniques such as exercises that can be done in the form of isometric, isotonic, aerobic and aquatic exercises. These types of exercises usually aim to improve range of motion, increase strength, coordination, endurance, balance and posture. Exercise can be done actively where the patient controls their own movements without the help of others or passively where the movements are carried out based on help from a physiotherapist. Exercise therapy can be done in the rehabilitation phase of various types of disorders such as stroke, joint replacement or aging.

While the provision of exercise techniques Thermotherapy (Heat therapy / Heat Therapy) is a therapy using heat temperatures are usually used in combination with other physiotherapy modalities such as exercise and manual therapy. Warm moist air can be used to reduce muscle stiffness and pain. Heat therapy can be done by using various methods, including using hot packs, warm towels, hot water bottles, ultrasound devices, infra-red devices and liquid paraffin tanks. This therapy can also be combined with hydrotherapy because warm water can relax muscles, joints and increase joint reach.

It can be concluded that there is an influence of giving physiotherapy to increase the leg and heart muscle power of PGN athletes, and the administration of control group physiotherapy with Exercise therapy techniques is more dominant than the administration of Thermotherapy (Heat therapy / Heat Therapy).
Effects of Nutritional Needs Based on RDA on Increased Leg and Heart Muscle Power: The t-value for the provision of nutritional requirements based on the RDA in the control group was 8.944 with a probability (sig.) Of 0.000 , because the probability value (sig.) Of $0.000<0.05$. While the value of t-count in the provision of nutritional needs based on the RDA of the experimental group is 4.648 and the probability (sig.) 0.002 , because the probability value (sig.) 0.002 $<0.05$. Thus there is an influence from the provision of increased muscle power to increase the leg and heart muscle power of PGN athletes.

Nutrition adequacy for nutritional adequacy in the control group with $900 \mathrm{kcal}$ breakfast calories, 500 kcal snacks, $1200 \mathrm{kcal}$ lunches, $1000 \mathrm{kcal}$ dinners and $600 \mathrm{kcal}$ snacks and compared to menu items in the experimental group with $1050 \mathrm{kcal}$ breakfast meals, light meals $700 \mathrm{kcal}$, lunch $1350 \mathrm{kcal}, 1150 \mathrm{kcal}$ dinner and $750 \mathrm{kcal}$ snacks are more effective for increasing the leg and heart muscle strength of PGN athletes as evidenced by the higher evaluation group average score of 8.20 while the average value of the control group which is 8.00 .

The results of the assessment of sports nutritionists show that with optimal food, enough energy can be available so that work ability and recovery time is better. Fatigue can be dealt with more effectively because reserve nutrients can be used to return to a homeostatic state. Nutrition for athletes is designed to achieve optimal nutrition adequacy.

Food for an athlete must contain high substances in accordance with those needed for daily activities. Food must contain a certain amount of energy-producing nutrients. Accordingly, food must also be able to replace gzi in the body which is reduced due to use for sports activities. Body movements during exercise can occur due to muscle contraction. Aerobic and anaerobic exercise both require energy intake. However, determining the energy requirements properly is not simple and very difficult. The development of science now can only calculate energy needs based on the energy expended. ${ }^{6}$

Sports nutrition is applied nutrition to athletes to be able to achieve optimal performance. Sports nutrition is the study of the relationship between food management and physical performance that is beneficial for health, fitness, child growth and the promotion of sports 
achievements. Nutrition settings for athletes are not much different from those for non-athletes ${ }^{7}$

It can be concluded that there is an influence of nutritional needs based on the nutritional adequacy rate on the increase in leg and heart muscle power of the Racecour De Singkarak Road Racecourse, with the average experimental group being more dominant than the control group.

\section{Conclusion}

Based on the results of data analysis and discussion in the previous chapter, the conclusions in this study are:

1. There is an effect of giving massage to increase leg and heart muscle power, with the average rating of the experimental group using the Strocking Effleurage, traction and Effleurage methods more dominant than the average value of the control group.

2. There is an influence of the provision of physiotherapy to increase the leg and heart muscle power of PGN athletes, and the administration of control group physiotherapy with Exercise therapy techniques is more dominant than the administration of Thermotherapy (Heat therapy / Heat Therapy).

3. There is an influence of nutritional needs based on the Recommended Dietary Allowances (RDA) on the increase in leg and heart muscle power of the Racecour De Singkarak Road Racecourse, with the average experimental group being more dominant than the control group.

Source of Fund: Self
Ethical Approval: Universitas Negeri Padang Tahun 2019.

Conflict of interest : nil

\section{References}

1. Giam CK, Teh KC. Ilmu kedokteran olahraga. Diterjemahkan oleh Satmoko H. Jakarta: Binarupa Aksara. 1993.

2. Harsono MS, Drs MS. Coaching dan Aspek-aspek Psikologis dalam Coaching. Direktorat Jendral Pendidikan Tinggi: Jakarta. 1988.

3. Halim NI. Tes dan pengukuran kesegaran jasmani. Makassar: Badan Penerbit UNM. 2011.

4. Johnson J,. Deep Tissue Massage (Hands-On Guides For Therapists). Human Kinetics. Kemenkes.2011

5. Arovah NI. Dasar-dasar fisioterapi pada cedera olahraga. Yogyakarta: FIK UNY. 2010.

6. Anggela TS, Damayanti I. Perbandingan Penggunaan Kalori Atlet Pencak Silat Kategori Seni Tunggal Dengan Seni Regu Baku Tingkat Remaja Puteri Rd Fighting Club Subang. Jurnal Terapan Ilmu Keolahragaan. 2018;1(2):44-52

7. Putri MC, Effendi H, Bafirman B. Tinjauan Kebugaran Jasmani dan Status Gizi Siswa Tunagrahita Ringan Sekolah Luar Biasa Negeri 1 Limau Manis Padang. Jurnal Sporta Saintika.; 3(2):463-9.

8. Brummitt J. The role of massage in sports performance and rehabilitation: current evidence and future direction. North American journal of sports physical therapy. 2018. 